\title{
Return of postpartum ovarian activity in dairy goats supplemented with different levels of energy ${ }^{1}$
}

\author{
Retorno da atividade ovariana pós parto em cabras leiteiras suplementadas com \\ diferentes níveis de energia
}

\begin{abstract}
NASCIMENTO, Thiago Vinicius Costa ${ }^{2 *}$; MIRANDA, Mayara de Souza ${ }^{2}$; BARROS, Celso Henrique Souza Costa ${ }^{3}$; SOUZA, Thaís Thatiane dos Santos ${ }^{4}$; LOPES JÚNIOR, Edilson Soares ${ }^{5}$; VOLTOLINI, Tadeu Vinhas ${ }^{6}$; MORAES, Salete Alves de ${ }^{6}$; NOGUEIRA, Daniel Maia ${ }^{6}$; CORDEIRO, Mabel Freitas ${ }^{5}$
\end{abstract}

\footnotetext{
${ }^{1}$ Parte da dissertação de Mestrado do primeiro autor, financiada pela Fundação de Amparo à Ciência e Tecnologia de Pernambuco (FACEPE).

${ }^{2}$ Universidade Federal da Bahia, Escola de Medicina Veterinária e Zootecnia, Programa de PósGraduação em Zootecnia, Salvador Bahia, Brasil.

${ }^{3}$ Universidade Federal do Maranhão, Programa de Pós-Graduação em Ciência Animal, Chapadinha, Maranhão, Brasil.

${ }^{4}$ Universidade Federal do Vale do São Francisco, Programa de Pós-Graduação em Ciência Animal, Petrolina, Pernambuco, Brasil.

${ }^{5}$ Universidade Federal do Vale do São Francisco, Laboratório de Fisiologia e Biotecnologia da Reprodução Animal, Petrolina, Pernambuco, Brasil.

${ }^{6}$ Embrapa Semiárido, Centro de Pesquisa Agropecuária do Trópico Semiárido, Petrolina, Pernambuco, Brasil.

*Endereço para correspondência: thiagoven_vet@ hotmail.com
}

\section{SUMMARY}

This study aimed to evaluate the return of post partum ovarian activity in dairy goats supplemented with different levels of energy during the dry period in the semi-arid region of Pernambuco. Twenty-four animals were allocated into four treatments of six animals each: Control, consisting of goats that had access to pasture and only received $4 \mathrm{~kg}$ of fresh palm, and three groups with isoproteic supplementation (20\% Crude Protein), ranging in TDN content of $65 \%, 75 \%$ and $85 \%$. The daily milk yield showed a linear growth behavior $(\mathrm{P}<0.05)$ since day $35^{\text {th }}$ postpartum, when the animals recovered the weight gain and body condition score after 14 and 21 days postpartum, respectively, with slight weight gain in $75 \%$ and $85 \%$ treatments. Among the reproductive parameters, uterine involution and return to estrus activity showed a decrease in the number of days associated with the higher energy levels $(\mathrm{P}<0.05)$. The emergence of the 1 st follicles $\geq 2 \mathrm{~mm}$ occurred around 33 days postpartum and the maximum diameter of the pre-ovulatory follicle was $5,41 \mathrm{~mm}$. These results were not influenced by treatments $(\mathrm{P}>$ 0.05). We concluded that the supplementation with different levels of energy promoted a positive effect, as increased productive parameters and reduced the number of days for the reestablishment of the reproductive parameters postpartum; for instance, uterine involution, return to estrus and consequently return of ovarian activity postpartum.

Keywords: goats, oestrus, uterine involution, postpartum

\section{RESUMO}

Objetivou-se com este trabalho avaliar o retorno da atividade ovariana puerperal de cabras leiteiras suplementadas com diferentes níveis de energia durante o período seco do semiárido pernambucano. Foram utilizados 24 animais divididos em quatro tratamentos, com seis réplicas cada: Grupo Controle, formado por cabras que tiveram acesso apenas ao pasto e 
receberam $4 \mathrm{~kg}$ de palma in natura; e três grupos com suplementação, feita com concentrados isoprotéicos, com $20 \%$ PB, variando o teor de NDT em $65 \%, 75 \%$ e $85 \%$. A produção diaria de leite apresentou um comportamento de crescimento linear $(\mathrm{P}<0,05)$ a partir do $35^{\circ}$ dia pós-parto, os animais exibiram retomada do ganho de peso e escore corporal por volta dos $14^{\circ}$ e $21^{\circ}$ dias pós-parto, respectivamente, com ligeiro ganho de peso total nos tratamentos $75 \%$ e $85 \%$. Dentre os parametros reprodutivos, a involução uterina e o retorno ao estro, apresentaram um decrecimo do numero de dias com o aumento do nivel de energia $(\mathrm{P}<0,05)$. Já o surgimento do $1^{\circ}$ folículo $\geq 2 \mathrm{~mm}$, ocorreu por volta do $33^{\circ}$ dia pós-parto e o diametro médio máximo do foliculo preovulatório foi de $5,41 \mathrm{~mm}$, todavianão foram influenciados pelos tratamentos $(\mathrm{P}>0,05)$. Conclui-se que a suplementação com níveis de energia, promoveu efeito positivo, como o aumento dos parâmetros produtivos e redução do número de dias pós-parto para o restabelecimento dos parâmetros reprodutivos: a involução uterina, retorno ao estro e consequentemente retorno da atividade ovariana pós-parto.

Palavras-chave: caprinos, estro, involução uterina, pós-parto

\section{INTRODUCTION}

The availability of nutrients is a fundamental factor regulating reproductive function in females, and undernutrition may to stop breeding activity (ZARAZAGA et al., 2004; VAN KNEGSEL et al., 2005; SALMAZO et al., 2008). During the dry season, substantial losses are observed in the availability and quality of forage, affecting thereby the body condition of the animals and reducing the productive and reproductive performance of animals (SALMAZO et al., 2008). The use of energetic nutritional supplementation during this period can induce to estrus behavior and ovulation (TORREÃO et al., 2008). Several researches have shown that the nutritional and metabolic states of the animal affect reproductive functions (MAHDI \& KHALLILI, 2008; SaLmazo et al., 2008; TORREÃO et al., 2008). Nevertheless, there are limited number of reports that have studied the mechanisms by which nutritional factors affect the hypothalamicpituitary-ovarian and the return of postpartum ovarian activity (puerperal period). It is known that energy is the main nutrient required by females for reproduction and inadequate supply of energy has a deleterious effect in the reproductive efficiency (ELOY et al., 2003; SARTORI \& MOLLO, 2007). In the postpartum period, it is necessary to increase the energy requirement of females that are in negative energy balance (NEB), especially in the first eight weeks postpartum, when there is an increase in the lactation curve (ALMEIDA et al., 2007). The effects of NEB on fertility appear to be mediated by metabolic and endocrine disorders, which result in changes in ovarian activity, and also reduce the viability of the oocyte to be fertilized. To reduce these negative effects, it is necessary that females have adequate body condition at the end of pregnancy, associated with necessary nutrition in the final third of pregnancy and during the postpartum, therefore, the resumption of weight and body condition score (BCS) occurs as early as possible, favoring the return of ovarian activity (MBAYAHAGA et al., 1998; ZARAZAGA et al., 2004). The return of ovarian follicular activity is marked by the return of follicular dynamics, which is a continuous growth and regression of antral follicles, which allows the development of preovulatory follicle (EMERICK et al., 2010).

In this context, this study aimed to evaluate the return of postpartum ovarian activity in dairy goats supplemented with different levels of 
Rev. Bras. Saúde Prod. Anim., Salvador, v.15, n.4, p.1061-1071 out./dez., 2014 http://www.rbspa.ufba.br ISSN 15199940

energy during the dry season in semiarid region of Pernambuco.

\section{MATERIAL AND METHODS}

The experiment was conducted in Umburana Farm, located in Santa Maria da Boa Vista, Pernambuco, Brazil. The town is situated at $8^{\circ} 48$ 'S, 39 $49^{\circ} 49^{\prime} \mathrm{W}$, at an altitude of $447 \mathrm{~m}$, and it has an average annual temperature of $25.5^{\circ} \mathrm{C}$. The experiment was carried out from July to October 2011, during the dry season of the year.

A total of 24 female goats with mean bodyweight of $45.05 \pm 5.08 \mathrm{~kg}$, and recently kidding were homogeneously distributed according to age, body condition, reproductive history, and allocated into four groups of six animals each: Control group $(n=6)$ had access only to cultivated pastures of Tifton 85 (Cynodon spp.), from 8 to 15 hours and, after returning from the pasture, received in indoor facilities, an average of $4 \mathrm{~kg}$ /animal of chopped fresh cactus (Opuntia ficus -indica Mill.), and water ad libitum and mineral supplementation. The other groups underwent the same management of the Control group, and have received 400 grams of isoproteic concentrate containing $20 \%$ of crude protein $(\mathrm{CP})$ and varying the TDN (total digestible nutrients) according to treatment: Group 65\% $(n=6)$ received concentrate containing $65 \%$ TDN, given the minimum energy requirement of goats at puerperium, as recommended by the NRC (2007), Group 75\% ( $=6)$ received concentrate containing $75 \%$ TDN, and Group 85\% $(\mathrm{n}=6)$ received a concentrate formulated with $85 \%$ TDN (Table 1).

Table 1. Proportion of ingredients and chemical composition of the diets

\begin{tabular}{|c|c|c|c|c|c|}
\hline \multicolumn{6}{|c|}{ Concentrates (\% NM) } \\
\hline Ingredients & & $65 \%$ & & $75 \%$ & $85 \%$ \\
\hline Ground corn & & 17.6 & & 48.0 & 41.4 \\
\hline Soybean meal & & 13.0 & & 16.0 & 28.2 \\
\hline Soybean oil & & 0 & & 0 & 8.0 \\
\hline Soybean hull & & 32.4 & & 0 & 0 \\
\hline Sodium chloride & & 3.0 & & 3.0 & 3.0 \\
\hline Mineral salt & & 3.0 & & 3.0 & 3.0 \\
\hline Calcareous & & 0.5 & & 0.5 & 0.5 \\
\hline Urea & & 2.2 & & 2.0 & 1.0 \\
\hline Wheat meal & & 28.3 & & 27.5 & 14.9 \\
\hline \multicolumn{6}{|c|}{ Chemical composition } \\
\hline & Tifton85 & Cactus & $65 \%$ & $75 \%$ & $85 \%$ \\
\hline $\mathrm{DM}$ & 33.63 & 9.94 & 87.51 & 82.79 & 84.59 \\
\hline $\mathrm{CP}$ & 7.89 & 2.91 & 22.44 & 22.14 & 22.03 \\
\hline $\mathrm{NDF}$ & 61.45 & 28.98 & 38.57 & 22.98 & 18.23 \\
\hline $\mathrm{ADF}$ & 32.09 & 18.53 & 22.55 & 9.86 & 8.69 \\
\hline $\mathrm{EE}$ & 1.48 & 1.56 & 2.59 & 3.64 & 10.93 \\
\hline Ash & 8.40 & 16.70 & 11.03 & 10.48 & 10.37 \\
\hline IVDDM & 58.01 & 62.32 & 64.83 & 73.41 & 68.55 \\
\hline
\end{tabular}


Regarding the handling of kids, they remained full-time with their mothers until day 15 postpartum. From day 16, the kids were separated from the goats at night, until they were 30 days after birth, when the kids were weaned.

For the assessment of body condition, we used the body condition score, using a scale of 1 (scrawny animal) to 5 (fat animal) (CEZAR \& SOUSA, 2006). Assessments of body condition and weight measurements were performed concomitantly: 3-5 days before parturition, on parturition day, and every 14 days, before the animals go to pasture Tifton 85 (Cynodon spp.). For the assessment of body condition score, weight gain and measurement of milk production, the animals were monitored until the 56th day postpartum.

The daily milk production was measured by manual milking, from day 14 postpartum and every seven days, once a day. The milk was measured in a beaker, and the means of production were used to obtain the lactation curve of each group (SILVA et al., 2009).

The uterine involution and the return of postpartum ovarian activity were evaluated by ultrasound. The evaluation of uterine involution was initiated 48 hours after birth, every three days, until the complete uterine involution, through the evaluation of uterine characteristics in ultrasonography.

Regarding to the observation of ovarian follicular activity by ultrasound, images from the ovaries were obtained from all animals in order for monitoring the follicular dynamics postpartum until the first ovulation every seven days (ELOY et al., 2003). The day of the return of the postpartum ovarian activity was marked by the emergence of the first follicular wave, observed by one or more follicles larger than $2 \mathrm{~mm}$ in diameter. The follicular diameter was obtained the greater distance ( $\mathrm{mm})$ between two points of the antral cavity in the follicle (URIBE-VELÁSQUEZ et al., 2010). The diameter, location and characteristics of antral follicles with at least $2 \mathrm{~mm}$ in diameter were recorded as described by Castro et al. (1999).

The does were also observed to clinical signs of oestrous behavior, through the use of bucks, once a day, from the 20th day after parturition to the onset of estrus, which were classified as being in oestrus when the females allowed to be mounted by a mature buck (ELOY et al., 2003).

The experimental design was a completely randomized of four treatments with six replicates per treatment. Data were subjected to analysis of variance (ANOVA), the program ASSISTAT v. 7.6 Beta (2011), and analysis of regression. Values were considered statistically significant when presented significance level of less than $5 \%$ probability ( $\mathrm{P}<0.05)$. Pearson correlations were calculated between the period of uterine involution and following parameters: number of offspring, total weight of the offspring, age of the female, order of parity, energy levels of concentrate, and time of return to estrus: BCS.

\section{RESULTS AND DISCUSSION}

Table 2 shows the daily milk yield, where the group 75\% TDN presented greater $(\mathrm{P}<0.05)$ daily milk yield from days $35^{\text {th }}$ to $56^{\text {th }}$. During these days, the analysis of regression showed an increased linear effect. 
Rev. Bras. Saúde Prod. Anim., Salvador, v.15, n.4, p.1061-1071 out./dez., 2014 http://www.rbspa.ufba.br ISSN 15199940

Table 2. Daily milk yield during seven weeks of evaluations, starting after the second week of parturition.

\begin{tabular}{|c|c|c|c|c|c|c|c|c|}
\hline \multirow{2}{*}{$\begin{array}{c}\text { Collect } \\
\text { days }\end{array}$} & \multirow{2}{*}{ control } & \multirow{2}{*}{$65 \%$} & \multirow{2}{*}{$75 \%$} & \multirow{2}{*}{$85 \%$} & \multirow{2}{*}{ SEM $^{*}$} & \multicolumn{2}{|c|}{$P$ value } & \multirow{2}{*}{$\begin{array}{l}\text { Regression } \\
\text { equation }\end{array}$} \\
\hline & & & & & & linear & square & \\
\hline Day $14^{\text {th }}$ & 590 & 608 & 617 & 617 & 37.56 & 0.81 & 0.91 & $\mathrm{Y}=608$ \\
\hline Day $21^{\text {th }}$ & 690 & 558 & 820 & 700 & 53.97 & 0.55 & 0.95 & $Y=692$ \\
\hline Day $28^{\text {th }}$ & 570 & 642 & 950 & 808 & 61.55 & 0.06 & 0.36 & $Y=743$ \\
\hline Day $35^{\text {th }}$ & 510 & 708 & 1075 & 1017 & 74.01 & 0.02 & 0.30 & $Y=485.12+6.09 x$ \\
\hline Day $42^{\text {th }}$ & 660 & 730 & 1192 & 1017 & 78.21 & 0.02 & 0.38 & $Y=634.35+4.72 x$ \\
\hline Day $49^{\text {th }}$ & 700 & 780 & 1250 & 1067 & 74.53 & 0.01 & 0.31 & $Y=674.79+4.88 x$ \\
\hline Day $56^{\text {th }}$ & 730 & 860 & 1333 & 1125 & 83.23 & 0.02 & 0.26 & $Y=709.03+5.39 x$ \\
\hline
\end{tabular}

*Standard error of the mean

Thus, the highest levels of energy favoured milk production. These data are in agreement with those reported by Barros et al. (1992), which evaluated the lactation curve of Anglo-Nubian goats receiving different levels of energy and observed that there is significant interaction between lactation period and the level of supplementation. Similarly, Zambom et al. (2005) also reported that higher energy levels provide greater milk production in goats. Lucena et al. (2006) found that a greater amount of concentrate in the feed supplementation, therefore, a higher intake of protein and energy, promotes greater milk production in Anglo-Nubian goats.

Regarding to the BCS, at the time 3 to 5 days before delivery, the animals showed an average BCS of 2.38; 2.50; $2.40 ; 2.40$ for groups $85 \%, 75 \% ; 65 \%$ and Control, respectively.

Table 3 shows that the group $85 \%$ had the BCS recovered soon after birth, which differs with the findings of Freitas et al. (2004), who stated that the resumption of BCS of goats occurred around the 28th day postpartum.

Table 3. Moments of the resumption of the body condition score (BCS), the early resumption of body weight (BW) and total body weight gain (TWG) (mean \pm s.e.m) of the experimental groups

\begin{tabular}{lccc}
\hline Treatments & $\begin{array}{c}\text { Recovery of BCS } \\
(\text { day })\end{array}$ & $\begin{array}{c}\text { Recovery of BW } \\
(\text { day })\end{array}$ & TWG (Kg) \\
\hline $85 \%$ & Postpartum & $14^{\circ}$ & 1,02 \\
$75 \%$ & $14^{\circ}$ & $14^{\circ}$ & 0,30 \\
$65 \%$ & $42^{\circ}$ & $28^{\circ}$ & $-0,42$ \\
Control & $14^{\circ}$ & $28^{\circ}$ & $-0,14$ \\
\hline Average & $14^{\circ}$ & $21^{\circ}$ & 0,18 \\
\hline
\end{tabular}

The early resumption of $\mathrm{BW}$ in the last two groups (Table 3) is in agreement with the data de Barros et al. (1992). The earlier recovery of the BW in groups $85 \%$ and $75 \%$, even without statistical difference (P> 0.05), promoted weight gain during the first 8 weeks postpartum, whereas groups $65 \%$ and Control showed a slight weight loss, but without statistical difference 
(P> 0.05), which may indicate a stronger effect of negative energy balance (NEB) in the Control and 65\% groups.

The NEB effects is deleterious in the reproductive parameters. This deleterious action was observed through in the uterine involution and showed a negative linear effect of treatments (Table 4).

The period of uterine involution corroborates the data observed by
Simplicio et al. (2000), who reported that goats have their uterine involution completed after 35 to 45 days postpartum.In addition, SalmitoVanderley \& Marques Júnior (2004), who worked with non described goats, reported that uterine involution was complete around 30 days postpartum (Figure 1).

Table 4. Period in days for the occurrence of uterine involution, the rise of $1^{\text {st }}$ follicle $\geq$ $2 \mathrm{~mm}$, the time to return to estrus and ultimately to the point of maximum diameter $(\mathrm{mm})$ of the preovulatory follicle $(\mathrm{POF})$ in dairy goats.

\begin{tabular}{|c|c|c|c|c|c|c|c|c|}
\hline \multirow{2}{*}{ Treatment } & \multirow{2}{*}{ Control } & \multirow{2}{*}{$65 \%$} & \multirow{2}{*}{$75 \%$} & \multirow{2}{*}{$85 \%$} & \multirow{2}{*}{ SEM* } & \multicolumn{2}{|c|}{$P$ value } & \multirow{2}{*}{$\begin{array}{l}\text { Regression } \\
\text { equation }\end{array}$} \\
\hline & & & & & & linear & square & \\
\hline $\begin{array}{l}\text { Involution } \\
\text { (days) }\end{array}$ & 36.8 & 36.3 & 29.5 & 32.0 & 1.17 & 0.04 & 0.49 & $Y=37.24-0.06 x$ \\
\hline $\begin{array}{l}\text { Appear } 1^{\text {st }} \text { follicle } \\
\text { (days) }\end{array}$ & 35.2 & 33.4 & 33.0 & 32.3 & 1.10 & 0.22 & 0.80 & $\mathrm{Y}=33.41$ \\
\hline $\begin{array}{l}\text { Return to estrus } \\
\text { (days) }\end{array}$ & 84.6 & 82.4 & 73.2 & 70.0 & 2.35 & 0.01 & 0.89 & $\begin{array}{c}Y=85.78- \\
0.15 x\end{array}$ \\
\hline $\begin{array}{l}\text { Maximum } \\
\text { diameter of } \\
\text { POF }(\mathrm{mm})\end{array}$ & 5.31 & 5.38 & 5.46 & 5.43 & 0.06 & 0.08 & 0.75 & $\mathrm{Y}=5.41$ \\
\hline
\end{tabular}

*Standard error of the mean

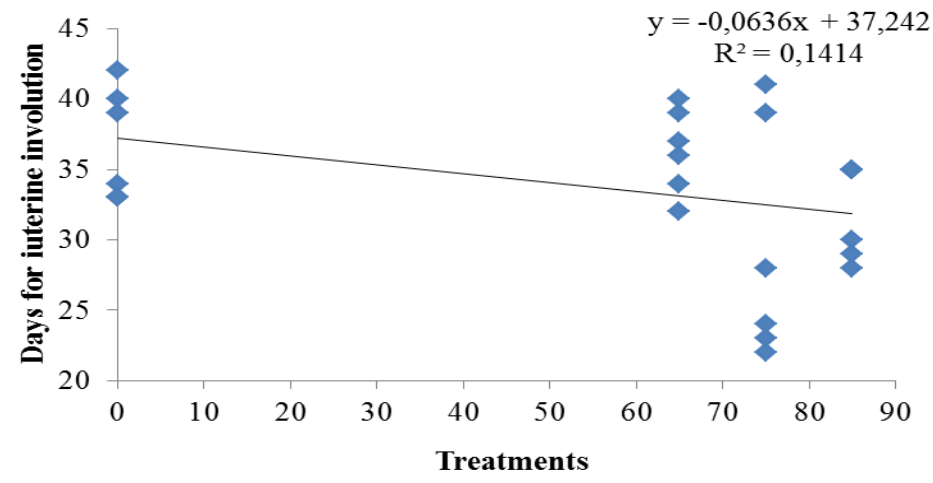

Figure 1. Regression line between the number of days for uterine involution and the levels of energy in the diet.

In this study, the duration of uterine involution in dairy goats was greater than those reported by Degefa et al.
(2006), who evaluated the uterine involution in Balady goats, a Jordan native breed, studying the macroscopic 
and microscopic aspects. These authors concluded that uterine involution in this breed occurs in 19 days postpartum. Similar results were observed by Takayama et al.(2010) in Shiba goats, both breeds are little size, and these goats have smaller uterus, which needs less time for return to the initial size.

In the present study, we observed a weak positive correlation between the period of uterine involution and the: number of offspring $(r=0.247797)$, total weight of the offspring $(\mathrm{r}=$ $0.2350072)$, age of the does $(\mathrm{r}=$ $0.2760678)$, order of parity ( $\mathrm{r}=$ 0.196216), and a weak negative correlation with the energy levels of concentrate $(r=-0.345682)$, which shows that there is an interaction between these factors of individual female, which are also associated with the availability of energy to promote the uterine involution.
Regarding the emergence of $1^{\text {st }}$ follicles $\geq 2 \mathrm{~mm}$, there was no statistical difference between treatments (P) $0.05)$. A low negative correlation was found between the rise of $1^{\circ}$ follicles $\geq$ $2 \mathrm{~mm}$ and the energy levels of concentrate $(r=-0.198422)$, showing that the available energy is one of the factors that influence the return of ovarian activity. In addition, a weak positive correlations was observed between the rise of $1^{\circ}$ follicles $\geq 2 \mathrm{~mm}$ and the: milk production $(\mathrm{r}=0.09337)$, and weight change $(r=0.005748)$.

The evaluation of estrous behavior showed a negative linear regression with the increased levels of energy in the treatments. Animals in groups $85 \%$ and $75 \%$ needed less time of return to estrous presenting statistical difference (P> 0.05), (Figure 2).

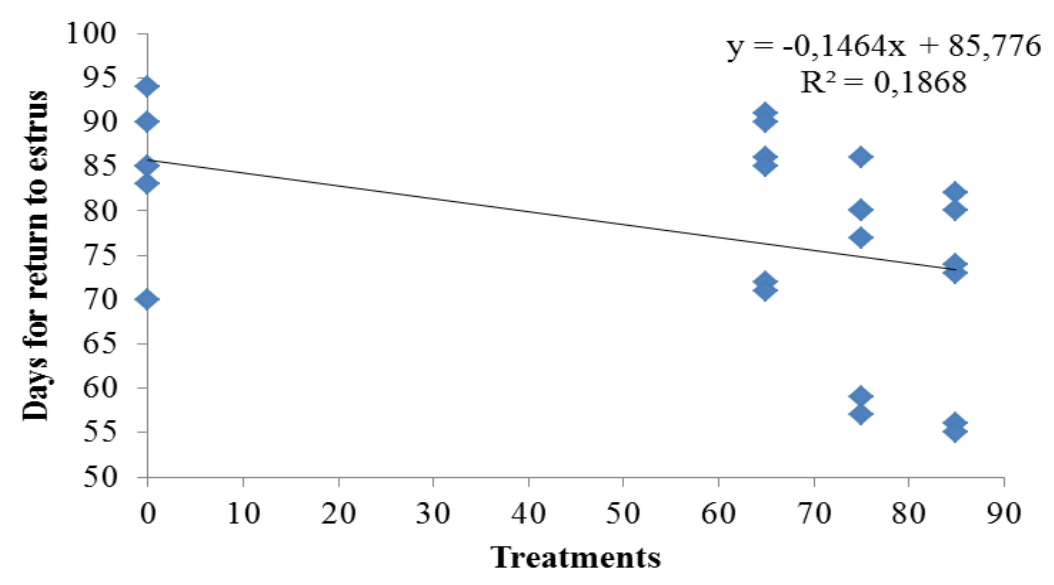

Figure 2. Regression line between the number of days for the return of estrus and the levels of energy in the diet

In this study, the mean number of days to the return of estrous activity was lower than those found by Eloy et al. (2003), who, worked with non-defined genotype goats in the dry period, and they found an average of $109.40 \pm 8.71$ days for the return of estrous activity.
Khanum et al. (2007) observed in Dwarf goats an fluctuation of 15 to 59 days for return to estrus. These authors explain that this quick return to oestrus activity is because these goats have small size, with an average bodyweight of $17 \mathrm{~kg}(13.9-20.0 \mathrm{~kg})$. Similar results 
were observed by Yagoub et al.(2013) in Nubian goats with similar bodyweight, who made comparisons with different breeds and they concluded that the size of the animal also strongly interferes to the return of estrus. Salmazo et al. (2008), working with dairy cows, found that higher levels of supplementation provide a shorter period of postpartum anestrus, anticipating the beginning of follicular activity and follicular growth. The same authors reported that there is a relationship between energy balance and reproductive efficiency, which are regulated by IGF-I and the Luteinizing Hormone (LH). When there is a reduction in plasma concentrations of insulin and, consequently, IGF-I and IGF-II, there is also a reduction in the secretion of hypothalamic Gonadotrophin Releasing Hormone $(\mathrm{GnRH})$, interfering with pulsatility of pituitary hormones, the Follicle Stimulating Hormone (FSH) and Luteinizing Hormone (LH) causing, as a consequence, a reduction in the rate of proliferation of granulosa cells and the activity of the Aromatase enzyme (SPICER et al., 2002; SCARAMUZZI et al., 2006; SALMAZO et al., 2008). Mahdi \& Khallili (2008) observed in sheep that low LH pulsatility during the first four weeks of the postpartum period in the NEB is rainsed, is the limiting factor for the resumption of ovarian activity. Therefore, this is a possible explanation for a decrease of days at postpartum anoestrus $(\mathrm{P}>0.05)$ found in this study. Another possible explanation is that the energy supplementation provides an increase in the number of follicles and an increased expression of aromatase activity, as reported in sheep by Muñoz-Gutiérrez et al. (2002).

Although there are studies showing that, when the animal is in feed restriction, there is no reduction of insulin release due to the low plasma glucose concentration, inducing mobilization of body reserves and thus reducing the activity of adipose tissue and release of leptin, with the consequence of increasing the concentration of neuropeptide $\mathrm{Y}$ at cerebrospinal fluid (ICHIMARU et al., 2001). This increased concentration of neuropeptide $\mathrm{Y}$ suppresses $\mathrm{GnRH}$ pulse generator, since this acts in modulating neurotransmitter generation of GnRH (ICHIMARU et al., 2001; OKAMURA \& OHKURA, 2007; SALMAN et al., 2007). Nutritional supplementation may promote the opposite to what was reported above, having a stimulation for the production of leptin induced by higher levels of circulating glucose, which afforded an increase of the release of insulin, IGF-I and IGF-II, inhibiting concentration of neuropeptide $\mathrm{Y}$ and thus allowing for greater release of GnRH(ICHIMARU et al., 2001).

We found a moderate negative correlation between the time of return to estrus and BCS ( $r=0.54440)$. Salmazo et al. (2008) also found a negative correlation between the return to estrus and the BCS at kidding. These authors described that improving BCS is related to increased energy reserves of the animal and thus signaling the body the possibility of resumption of sexual activity.

In this study, a weak correlation was found between the change in body weight and return to estrus ( $\mathrm{r}=$ 0.15366). Mbayahaga et al. (1998) stated that the onset of estrous behavior is influenced by variation in body weight, which was also observed in this experiment. In addition, weak positive correlations were observed between the time of return to estrus and the: milk production $(\mathrm{r}=0.048473)$, number of parturition $(r=0.15415)$, age of mother $(\mathrm{r}=0.30899)$; number of lactations $(\mathrm{r}=$ $0.236778)$, duration of uterine involution $(\mathrm{r}=0.31940)$, and the emergence of the first follicle $(r=$ 
0.14141 ), and, therefore, we can assert that the combination of these factors is responsible for return of estrous activity.

In this study, the mean maximum diameters of preovulatory follicle (POF) were superior to data from the first and second waves of ovulatory control group reported by Uribe-Velásquez et al. (2010), who showed that the maximum FPO diameter of $4.16 \pm 0.50$ $\mathrm{mm}$ and $4.66 \pm 0.50 \mathrm{~mm}$ for first and second follicular waves, respectively. However, the same authors observed that this same control group reached a maximum diameter in the third wave ovulatory of $5.5 \pm 0.50 \mathrm{~mm}$, similar to the data found in this work (Table 4).

In this study, it was observed through the weak positive correlation between the diameter of PFO and energy levels in the concentrate $(r=0.156245)$, that energy is a factor that, separately, has little influence on the maximum diameter of the PFO. Based on these results, supplementation with higher energy levels ( $85 \%$ of TDN) promoted a positive influence on productive and reproductive paramenters during the first eight weeks postpartum.

Supplementation with different levels of energy promoted a positive effect, as increased the productive parameters and reduce the number of days postpartum for the reestablishment of these reproductive parameters: uterine involution, return to estrus and, consequently, the return of ovarian activity postpartum.

\section{REFERENCES}

ALMEIDA, A.P.; SOUZA, A.L.; MENEZES, E.S.B.; ARRUDA, I.J.; RONDINA, D. Recentes avanços na relação entre nutrição e reprodução em ruminantes palestra In: Semana de
Nutrição e Alimentação Animal, 1, 2007, Fortaleza. Anais eletrônicos... Fortaleza: UFC, 2007. Disponível em: $<$ http://www.nutricaoanimal.ufc.br/1sna a/images/Palestra08h.pdf $>$. Acesso em: 08 nov. 2011.

ASSISTAT. Versão 7.6 Beta. Campina Grande, Paraíba, 2011.

BARROS, N.N.; MESQUITA, R.C.M.; SOUZA NETO, J.; ALVES, J.U.;

BARBIERI, M.E. Efeitos de níveis de energia sobre a produção de leite em cabras da raça Anglo-Nubiana.

Pesquisa Agropecuária Brasileira, v.27, n.1, p.119-130, 1992.

CASTRO, T. de; RUBIANES, E.; MENCHACA, A.; RIVERO, A.

Ovarian dynamics, serum estradiol and progesterone concentrations during the interovulatory interval in goats.

Theriogenology, v.52, p.399-411, 1999.

CEZAR, M. F.; SOUSA, W.H. de. Avaliação e utilização da condição corporal como ferramenta de melhoria da reprodução e produção de ovinos e caprinos de corte In: REUNIÃO

ANUAL DA SOCIEDADE BRASILEIRA DE ZOOTECNIA, 43, 2006, João Pessoa, PB. Anais... João Pessoa, PB: SBZ, 2006.

DEGEFA, T.; ABABNEH, M. M.; MOUSTAFA, M.F. Uterine involution in the post-partum Balady goat. Veterinarski Arhiv, v.76, n.2, p.119133, 2006.

ELOY, A.M.X.; ANDRIOLI, A.; SIMPLÍCIO, A.A. Atividade ovariana no pós-parto de cabras SRDs (sem raça definida) no nordeste do Brasil. Ars Veterinária, v.19, n.2, p.166-171, 2003. 
Rev. Bras. Saúde Prod. Anim., Salvador, v.15, n.4, p.1061-1071 out./dez., 2014 http://www.rbspa.ufba.br ISSN 15199940

EMERICK, L.L.; DIAS, J.C.;

GONÇALVES, P.E.M.; MARTINS, J.A.M.; SOUZA, F.A.; VALE FILHO, V.R.; ANDRADE, V.J. Retorno da atividade ovariana luteal cíclica de vacas de corte no pós-parto: uma revisão.

Revista Brasileira Reprodução Animal, v.33, n.4, p.203-212, 2010.

FREITAS, V.J.F., RONDINA, D., NOGUEIRA, D.M., SIMPLÍCIO, A.A. Post-partum anoestrus in Anglo-nubian and Saanen goats raised in the semi-arid region of Northeast of Brazil Livestock

Production Science, v.90, p.219-226, 2004.

ICHIMARU, T.; MORI, Y.; OKAMURA, H. A possible role of neuropeptide $\mathrm{Y}$ as a mediator of undernutrition to the hypothalamic gonadatropin-releasing hormone pulse generator in goats. Endocrinology, v.142, p.2489-2498, 2001.

KHANUM, S.A.; HUSSAIN, M.; KAUSAR, R. Assessment of reproductive parameters in female Dwarf goat (Capra hircus) on the basis of progesterone profiles Animal

Reproduction Science, v.102, p.267275, 2007.

LUCENA, J.A.; BISCONTINI, T.M.B.; CARVALHO, F.F.R.; VASCONCELOS, V.R.; SILVA, A.M.A.; LEITE, E.R. Desempenho produtivo de cabras em lactação submetidas a dois níveis de concentrado e somatotropina Bovina recombinante In: ZOOTEC, 2006, Recife. Anais... Recife, 2006.

MAHDI, D.; KHALLILI, K. Relationship between follicle growth and circulating gonadotrophin levels during postnatal development of sheep. Animal

Reproduction Science, v.106, p.100 112,2008

MBAYAHAGA, J.; MANDIKI, S.N.M.; BISTER, J.L.; PAQUAY, R. Body weight, oestrous and ovarian activity in local Burundian ewes and goats after parturition in the dry season Animal Reproduction Science, v.51, p.289-300, 1998.

MUÑOZ-GUTIÉRREZ, M.; BLANCHE, D.; MARTIN, G.B.; SCARAMUZI, R.J. Folliculogenesis and ovarian expresión of RNA encoding aromatase in anoestrous sheep after 5 days of glucose or glucosamine infusion or supplementary lupin feeding. Reproduction, v.124, p. 721-731, 2002.

NATIONAL RESEARCH COUNCIL NRC. Nutrient requeriments of small ruminants. 7thed. Washington: National Academic Press, 2007. 408p.

OKAMURA, H.; OHKURA, S. Neuroendocrine control of reproductive function in ruminants. Animal Science Journal, v.78, p.105-111, 2007.

SALMAN, A.K.D.; BERMAL, R.C.; GIACHETTO F.P.; Gene da Leptina em Ruminantes Revista Electrónica de Veterinaria, v.8, n.12, 2007.

SALMAZO, R.; MIZUBUTI, I.Y.; MOREIRA, F.B.; ROCHA, M.A. da; RIBEIRO, E.L.A.; SENEDA, M.M.; HIROKI, P.T.; KRAWULSKI, C.C.; RIGO, A.G.; SCHROEDER, R.V. Efeito de diferentes níveis de suplementação concentrada sobre o desempenho reprodutivo de vacas leiteiras mantidas a pasto. Ciências Agrárias, v.29, n.3, p.731-740, 2008.

SALMITO-VANDERLEY, C.S.B.; MARQUES JÚNIOR, A.P. Involução uterina em cabras sem raça definida Revista Brasileira de Reprodução Animal, v.28, n.3, p.278-281, 2004.

SARTORI, R.; MOLLO, M.R. Influência da ingestão alimentar na fisiologia reprodutiva da fêmea bovina. Revista Brasileira Reprodução Animal, v.31, n.2, p.197-204, 2007. 
Rev. Bras. Saúde Prod. Anim., Salvador, v.15, n.4, p.1061-1071 out./dez., 2014 http://www.rbspa.ufba.br ISSN 15199940

SCARAMUZZI, R.J.; CAMPBELL, B.K.; DOWNING, J.A.; KENDALL, N.R.; KHALID, M.; MUÑOZGUTIÉRREZ, M.; SOMCHIT, A. A review of the effects of supplementary nutrition in the ewe on the concentrations of reproductive and metabolic hormones and the 50 mechanisms that regulate folliculogenesis and ovulation rate.

Reproduction Nutrition Device, v.46, p.339-354, 2006.

SILVA, V.N.; RANGEL, A.H.N.; BRAGA, A.P.; MAIA, M.S.; MEDEIROS, H.R. Influência da raça, ordem e ano de parto sobre a produção de leite caprino. Acta Veterinaria, v.3, n.4, p.146-150, 2009.

SIMPLÍCIO, A.A.; SANTOS, D.O.; SALLES, H.O. Manejo de caprinos para a produção de leite em regiões tropicais Ciência Animal, v.10, n.1, p.13-27, 2000.

SPICER, L.J.; CHASE JUNIOR, C.C.; RUTTER, L.M. Relationship between serum insulin-like growth factor-I and genotype during the postpartum interval in beef cows. Journal of Animal Science, v.80, p.716-722, 2002.

TAKAYAMA, H.; TANAKA, T.; KAMOMAE, H. Postpartum ovarian activity and uterine involution in nonseasonal Shiba goats, with or without nursing (Short Communication) Small Ruminant Research, v.88, p.62-66, 2010.

TORREÃO, J.N.C.; PIMENTA FILHO, E.C.; MEDEIROS, A.N.; GONZAGA NETO, S.; CATANHO, M.T.J.A; BARRETO, L.M.G.; SILVA, J.O. Retorno da atividade cíclica reprodutiva em ovelhas da raça Morada Nova submetidas a diferentes níveis de energia metabolizável. Revista Brasileira de Saúde e Produção Animal [online], v.9, n.3, p. 621-630, 2008.
URIBE-VELÁSQUEZ, L.F.; SOUZA, M.I.L.; OSORIO, J.H. Resposta ovariana de cabras submetidas a implantes de progesterona seguidos de aplicações de gonadotrofina coriônica eqüina Revista Brasileira de Zootecnia, v.39, n.6, p.1214-1222, 2010.

VAN KNEGSEL, A. T. M.; VAN DEN BRAND, H.; DIJKSTRA, J.; TAMMINGA, S.; KEMP, B. Effect of dietary energy source on energy balance, production, metabolic disorders and reproduction in lactating dairy cattle. (Review). Reproduction Nutrition Device, v.45 p.665-688, 2005.

YAGOUB, M.S.; ALQURASH, A.M.; ELSHEIKH, A.S. Some reproductive traits of female Nubian goats Journal of American Science, v.9, n.5, p.385-389, 2013.

ZAMBOM, M.A.; ALCALDE, C.R.; MARTINS, E.N.; SANTOS, G.T.; MACEDO, F.A.F.; HORST, J.A.; VEIGA, D.R. Curva de Lactação e Qualidade do Leite de Cabras Saanen Recebendo Rações com Diferentes Relações Volumoso : Concentrado Revista Brasileira de Zootecnia, v.34, n.6, p.2515-2521, 2005.

ZARAZAGA, L.A.; GUZMÁN, J.L.; DOMÍNGUEZ, C.; PÉREZ, M.C.; PRIETO, R. Effect of plane of nutrition on seasonality of reproduction in Spanish Payoya goats Animal Reproduction Science, v.87, p.253-267, 2004.

Data de recebimento: $12 / 03 / 2014$

Data de aprovação: 20/11/2014 